\title{
Politeness in Interlanguage Pragmatics of Complaints by Indonesian Learners of English
}

\author{
Agus Wijayanto ${ }^{1}$, Malikatul Laila ${ }^{1}$, Aryati Prasetyarini ${ }^{1} \&$ Susiati Susiati ${ }^{1}$ \\ ${ }^{1}$ Prodi. Pendidikan Bahasa Inggris, FKIP Universitas Muhammadiyah Surakarta, Indonesia \\ Correspondence: Agus Wijayanto, Prodi. Pendidikan Bahasa Inggris, FKIP UMS. Tromol Pos I Pabelan \\ Kartasura-Surakarta, Jawa Tengah, 57102, Indonesia. Tel: 62-271-717-417-131. E-mail: agus.abdn@gmail.com
}

Received: June 22, 2013 Accepted: July 23, 2013 Online Published: September 4, 2013

doi:10.5539/elt.v6n10p188 URL: http://dx.doi.org/10.5539/elt.v6n10p188

\begin{abstract}
Complaint is intrinsically an abusive act which tends to offend the complainees. In spite of this complainers could consider politeness when they still intend to maintain a good relationship with the complainees. This paper investigated politeness strategies involved in complaints relating to different social status levels and social distances. The data of the complaints were elicited through oral discourse completion tasks from 50 Indonesian learners of English consisting of 25 males and 25 females. The findings indicated that most complaints sounded very direct, particularly those addressed to lower-unfamiliar interlocutors. Four politeness strategies of Brown and Levinson (1987) were employed by the learners. Bald on record and Positive politeness were the most pervasive strategies used across status levels and social distances. Negative politeness was comparatively high, but it was not as high as Bald on record and Positive politeness. Off-record was rarely phrased across status levels and social distances.
\end{abstract}

Keywords: interlanguage pragmatics, pragmatic competence, complaint, positive politeness, negative politeness

\section{Introduction}

\subsection{Rationale of the Study}

Pragmatic knowledge or competence is crucial to successful cross-cultural and interpersonal communication as it will facilitate interlocutors to convey their communicative intention and to comprehend the message as it is intended by other interlocutors (Bachman, 1990; Fraser, 2010). Having an inadequacy of this knowledge could engender pragmatic failure in which speakers could run the risk of appearing uncooperative, rude, and insulting (Bardovi-Harlig, Hartford, Mahan-Taylor, Morgan, \& Reynolds, 1991), and interlocutors tend to perceive a pragmatic failure as an offence rather than simply a deficiency in language knowledge (Thomas, 1983). In cross-cultural communication, lacking of pragmatic proficiencies could induce communication breakdown (Amaya, 2008; Lihui \& Jianbin, 2010).

Complaint is one of speech acts which could engender communication breakdown. It threatens an addressee's positive face as a complainer expresses negative evaluations of a situation which is the result of the addressee's past actions. It could also threaten the addressee's negative face as it may contain an implicit or explicit demand to rectify the aforementioned situation (Kraft \& Geluykens, 2002). As complaint intrinsically carries threat it often impairs social relationship between interlocutors (Moon, 2002; Olshtain \& Weinbach, 1993).

As complaining is commonly face-threatening, complainers could use politeness strategies if they intend to save complainees' face or at least to mitigate the severity of their complaints. For foreign language learners however to express politeness in a speech act which is intrinsically face-threatening could be very challenging as what is considered polite in their mother tongue could be rude in the target language context.

There has been increasing interest in analyzing the application of politeness by non-native speakers. Nevertheless research mostly covered the use of politeness in speech act of request (e.g., Al-Marrani \& Sazalie, 2010; Anderson, 2009; Marazita, 2009) whilst the same research on other face-threatening acts has been under explored. The present study examined the use of politeness strategies by Indonesian learners of English, with a focus on the type and frequency of politeness they employed when complaining in some different social situations. 


\subsection{Research Questions}

It was reported that speech act realizations were influenced by different social status (Al-Eryani, 2007), degree of formality (Félix-Brasdefer, 2006), and gender differences (Sadler and Eroz, 2002). In Indonesian sociocultural context, the use of speech act strategies was influenced by collocutors' status levels (Oktoprimasakti, 2006), familiarity between interlocutors (Astika, 2013), and face maintenance and gender (Prawito, 2007).

Considering the background above this research investigated the use of politeness strategies by Indonesian learners of English in relation to differences in social status levels and familiarity of interlocutors. The following research questions were raised: (1) Do Indonesian learners of English use politeness strategies when they make complaints? (2) Do different social distances (familiarity) instigate different use of politeness strategies? (3) Do different status levels (power) induce different use of politeness strategies?

\section{Literature Review}

\subsection{Speech Act of Complaint}

Complaint has been suggested as the expression of negative feelings relating to what speakers present as a complainable matter (Traverso, 2008). It often refers to "expression of dissatisfaction addressed by an individual A to an individual B concerning behaviour on the part of B that A feels unsatisfactory" (Laforest, 2002, p. 1596), or to the person the complainer deems responsible for an offence (North, 2000). Complaint often involves activities in which speakers point out some transgression or misconduct on the part of the subject who caused a trouble and performed some complainable action; such trouble or complainable activity usually includes a grievance on the part of the complainer (Edwards, 2005). In other words it is directed to the person who holds accountability for the trouble (Monzoni, 2008a; Schegloff, 1988). Complaint could be committed by accusing complainees' wrong doing (Frescura, 1995) and asking rhetorical questions (Koshik, 2003) or polar questions (Monzoni, 2008b).

Studies commonly differentiate between direct and indirect complaints. The former is aimed at someone who is present in the scene (Sauer, 2000; Boxer, 1999b) and is directly responsible or accountable for the troubles (Monzoni, 2008a). In the latter a speaker complains to a recipient about some absent party or external circumstances (Drew, 1998). Indirect complaint could build a social relationship or functions as socialization strategies (e.g. Boxer, 1999a, 1999b). Unlike that of Drew (1998), Boxer's indirect complaint is similar to trouble-telling (Jefferson, 1988) or gripping (Allami, 2006) in which the addressee is not held responsible for a perceived offence. Boxer (1999b) explained that indirect complaint is commonly initiated with moves relating to some themes such as self, situation, and other. In a self complaint a speaker expresses negative evaluation about himself or herself by criticizing her or his own ability, behaviour, actions, or physical appearance etc. In a situation-induced complaint a speaker complains about general problems for example, time, money, food, courses, weather, illness, fatigue and crime etc. In other complaints, speakers talk about other person(s). This type of complaint is commonly referred to as third party complaint.

Previous research revealed that English language learners used different complaint strategies as compared with native speakers of English. Trosborg (1995) compared the realization of requesting, complaining, and apologizing by Danish learners of English and native speakers of English. As to complaint strategies, the researcher reported that unlike the native speakers of English the learners used fewer complaint modifications and they tended to phrase their complaints unconvincingly and less forcefully. Murphy and Neu (1996) compared the realization of complaint by American native speakers of English and Korean learners of English. They reported that the native speakers of English hardly used criticism whilst the Korean learners of English tended to produce an aggressive and disrespectful criticism. A study by Tanck (2002) reported that non native speakers of English produced longer complaints than did native speakers of English, and they often used inappropriate complaints to collocutors of higher status. It was reported by Umar (2006) that Sudanese learners of English sounded more confrontational than did native speakers of British English when they made complaints since the learners involved much lower levels of courtesy in their complaints.

\subsection{Face-Work}

To date some models of face-work were conceptualized by some pioneers such as Goffman (1967), Lakoff (1977), Leech (1983), and Brown and Levinson (1987). Goffman (1967) views face as a public image in the flow of social events which is temporarily loaned to an individual from society as long as he or she is worth to it. To secure his or her public image he or she needs to perform face-work that is conducting an action consistent with face. Lakoff (1977) asserts that face-work is a cooperative transaction which governs human communication. She formulates it into three rules including formality: don't impose, remain aloof. This is the basic politeness strategy 
of avoiding imposition on others and the rule of maintaining social distance. The next rule is hesitancy which allows addressees their options - a strategy to respect private territories. The last is equality or camaraderie that is acting as though interlocutors were equal, and making them feel good. In contrast to the first rule, the last is the strategy to show informality in which all attributes regarding to social differences between interlocutors are removed for the sake of communication concord.

Brown and Levinson (1987) formulate the concept of face based on Goffman's face (1967). Central to Brown and Levinson's face-work is that an individual has two wants that is negative face- the basic claim to personal preserves and rights to non-distraction, and positive face - positive consistent self-image including the desire that this self-image is appreciated and approved of. In every social interaction interlocutors cooperate each other in order to maintain their face and everyone's face depends on everyone else's is being maintained. Owing to vulnerability of face in social interaction it can be lost, maintained, and enhanced.

Interlocutors employ strategies to minimize face threats when using some speech acts in which the selection of a strategy counts on the ways speakers weigh up the face threatening acts (FTA) in relation to hearers. Brown and Levinson suggest three aspects which can be used to calibrate the strength of FTA: P (power), D (social distance), and $\mathrm{R}$ (the degree of imposition). They furthermore assert that three wants have to be considered if speakers intend to communicate the FTA that is their want to communicate the contents of FTA, to be efficient, and to maintain hearers' face to any degree. If the speakers plan to do a FTA, they can do it in prescribed strategies: off-record and on-record. The former is commonly carried out by involving indirect linguistic realization whilst the latter can be performed without redress (baldly) and with redress by employing Positive and Negative politeness. Positive politeness addresses positive face, whilst Negative politeness satisfies negative face. When the risk of damaging a hearer's face is too great, the speaker can relinquish the FTA completely or 'don't do FTA'.

Research on politeness has been growing considerably since the concept of face-saving strategy was proposed by Brown and Levinson (1987). Literature on politeness often contrasts their work with other concepts of politeness across culture. For example in Japanese interpersonal communication, preserving social hierarchies is much more important than claiming freedom from imposition (Matsumoto, 1988). In Chinese sociocultural context, politeness (limáo) is not an individual's want to claim their private territory but rather a phenomenon which belongs to the level of society that is social principles to establish social bonds, strengthen solidarity, and control social distance $(\mathrm{Gu}, 1990)$. In Indonesia particularly in Javanese context, politeness concerns sopan and santun (Wijayanto, 2013). The former is other-oriented politeness which functions to attend other people's welfare including maintaining their rasa (feelings) and/or respecting their aji (self-worth). The latter signifies one's quality of being a Javanese. As a private or self orientation santun lacks similarities to Brown and Levinson's freedom from imposition but rather the maintenance of one's awareness to show propriety in manners and behaviour according to tata krama (etiquette) which could secure one from negative evaluation or appraisal by the public.

\section{Method}

\subsection{Research Participants}

To recruit the research participants, the researchers announced the intention of obtaining pragmatic data and explained the objectives of the research to undergraduate students of the English department of Muhammadiyah University of Surakarta, Indonesia. Those who were interested and agreed to voluntary participate in the research were recruited and they were selected through a random sampling technique. Participants taking part in this research consisted of 50 students comprising 25 males and 25 females who were in the second-year course of the degree of English education. The age of the students ranged between 18-20 years old, with the average age being 19.5 years. They reported that they have previously studied English for six years in secondary schools and two years at the English department. The level of their English was upper-intermediate. None of the participants went to English speaking countries previously and they never used English in naturalistic setting.

\subsection{Research Instrument}

Written discourse completion task (DCT) has been a very popular instrument of data elicitation in interlanguage pragmatic research. Data obtained through DCT has been claimed to represent appropriate pragmatic norms (Hinkel, 1997) and provide stereotypical responses which occur in spontaneous speeches of target native speakers (Beebe \& Cummings, 1996). As social situations in DCT are controlled, it provides varied responses according to different social aspects (Kwon, 2004). In foreign language learning contexts where natural usages of a target language rarely occur, DCT is a very effective instrument (Seran \& Sibel, 1997). Nevertheless written DCT has some drawbacks for example participants do not conversationally interact and they answer DCT scenarios based on what they believe will be appropriate responses (Golato, 2003). 
To retain the strength of written DCT whilst at the same time to overcome its downside, this study applied an oral DCT (referred to henceforth as ODCT) to elicit the research data. The ODCT designed for the present study consisted of scenario description which provided the research participants with a specific social situation, setting, speaker's roles, and relative status levels of collocutors. Based on the scenario description, research participants were required to respond each ODCT orally. Thus the ODCT would retain spontaneous responses.

The ODCT scenarios were designed to be as realistic as possible to Indonesian sociocultural contexts. They involved nine scenarios each of which represented one of three different status levels constituting either different age levels or occupation (lower, equal, and higher) and three social distances or familiarities (close, familiar, unfamiliar). They are summarized as follows.

Scenario 1: your close friend broke your new camera (complaining to a close-equal status).

Scenario 2: your brother borrowed your motorcycle and he returned it late (complaining to a close-lower status).

Scenario 3: your father forgot to give you money for your tuition fee (complaining to a close-higher status).

Scenario 4: your neighbor next door turned on rock music too loud (complaining to a familiar-equal status).

Scenario 5: your inferior has not finished the report as you ordered (complaining to a familiar-lower status).

Scenario 6: your lecturer gave you a low mark (complaining to familiar-higher status).

Scenario 7: a student cut your queue in a photocopy service centre (complaint to an unfamiliar-equal status).

Scenario 8: a busker next to you is playing a guitar too loud (complaining to an unfamiliar-lower status).

Scenario 9: an administrative staff ignores your presence (complaining to an unfamiliar-higher status).

\subsection{Data Analysis}

A modified taxonomy of complaint based on Trosborg (1995) was employed to classify complaint strategies used by the research participants. Complaint consists of utterances which function as head acts (the main strategies which express complaints) and supporting moves (additional information but does not state complaint) which initiate and/or follow the head acts. The head acts include the following strategies.

Strategy 1: No explicit reproach

A complainer uses hinting strategies in which case the complainable is not mentioned in the proposition. In other words the complainer does not directly state that something is bad or offensive.

\section{Strategy 2: Expression of annoyance}

This strategy involves the expression of annoyance, dislike, and disapproval, relating to a certain state of affairs the speaker considers bad for him or her. The utterance may also express the bad consequences resulting from an offence for which the complainee is held implicitly responsible.

\section{Strategy 3: Accusations}

Accusations are used by a complainer to establish the agent of a complainable. The complainer can ask the hearer questions about the situation or assert that he or she was in some way connected with the offence and thereby try to establish the hearer as a potential agent of the complainable (indirect accusation). Alternatively, the complainer can directly accuse the complainee of having committed the offence (direct accusation).

\section{Strategy 4: Blaming}

A complainer presupposes that the accused is guilty of the offence. This category includes two strategies: modified blame and explicit condemnation of action/person.

\section{Strategy 5: Asking for responsibility}

In this strategy a complainer asserts a state of affair in the presence of the complainee that the complainee holds responsible for the offence.

\section{Strategy 6: Warning}

Warning is given by a complainer to urge or advise the complainee to be careful and cautious as what she or he did or is doing has offended the complainer or someone else or third party.

\section{Strategy 7: Expressing disappointment}

Through this strategy a complainer expresses a feeling of dissatisfaction as his or her expectations towards the complainee are not realized. This also involves dissatisfaction to a state of affairs which is inconsistent with what the speaker expects. 


\section{Strategy 8: Threatening}

A threat is done by a complainer by expressing an intention to inflict pain, injury, punishment, and some other unpleasant consequences to the complainee.

\section{Strategy 9: Criticizing/rebuking/reproving/admonishing}

In this strategy a complainer expresses gentle to sharp and stern disapprovals relating to a certain state of affairs the speaker considers bad for him or her for which the complainee is held responsible.

Strategy 10: Requesting/ordering

This is the act of asking for something to be given or done. In Trosborg' (1995) taxonomy it is considered as "other" act which is not included as a main complaint strategy. In this research however, it is utilized by the research participants as a head act of a complaint.

Strategy 11: Letting off hook (forgiving and accepting the offence)

This is a strategy when a complainer relinquishes his or her complaint due to some sociocultural reasons. This strategy is done by forgiving the offenders and even accepting the complainable matters.

The politeness strategies involved in the complaints were analyzed based on Brown and Levinson (1987): Bald on record, Positive politeness, Negative politeness, and Off-record. Bald on record is employed whenever a speaker wants to do FTA with maximum efficiency more than he or she wants to satisfy the hearer's face. Positive politeness satisfies a hearer's positive face that is his or her desire that his or her wants (or the actions/acquisitions/values resulting from them) should be thought of as desirable. Negative politeness redresses a hearer's negative face that is the want to have freedom of action unhindered and their intention unimpeded. Off-record essentially involves an indirect use of language in which the speaker says something that is either more general or actually different from what he or she means (intends to be understood). An Off-record can be done in such a way that it is not possible to attribute only one clear communicative intention to the act.

Pearson's Chi square test $\left(\chi^{2}\right)$ with a confidence level of $95 \%$ or $\alpha=0.05$ was applied to test whether the use of each type of politeness strategies across status levels and social distances was significantly different.

\section{Results and Discussion}

The following sections discuss the use of politeness strategies and their frequencies. It should be noted that grammatical errors made by the participants were excluded from the analysis and discussion.

\subsection{Types of Politeness Strategies}

The four politeness strategies of Brown and Levinson (1987) were applied in complaints: Bald on record, Positive politeness, Negative politeness, and Off-record.

\subsubsection{Bald on Record}

In situation 1, 2, and 3, Bald on record was involved in many complaint strategies such as blaming, showing disappointment, asking for responsibility, expressing negative sequence, annoyance, and threatening.

1) I am sorry bro, this is my camera is broken because of you, so I really a complaint with you. (A response to scenario 1: direct blaming)

2) I need your responsible. (A response to scenario 1: asking for responsibility)

3) Oh my God, bro! You came late, now I think I will be late to go to college. (A response to scenario 2: negative sequence)

4) Hai brother! You are deaf! I will use it now. (A response to scenario 2: annoyance)

5) If you do it again, you cannot use again. (A response to scenario 2: threatening)

6) Dad, I'm very disappointed! (A response to scenario 3: expressing disappointment)

In situation 4, 5, and 6, Bald on record was also used in various complaint strategies, e.g. expressing annoyance, disappointment, requesting/ordering, criticizing, and warning.

7) Hey you crazy! You turn on music rock very loudly! (A response to scenario 4: annoyance)

8) Damn! Because I this day must to send to Jakarta! Fuck! You work out! Work out now! (A response to scenario 5: annoyance)

9) Turn off your-turn off radio please. (A response to scenario 4: requesting)

10) I feel disturb with that sound. You should know tomorrow I have examination. (A response to scenario 4: 
annoyance)

11) Hey you! You late give me your task! (A response to scenario 5: criticizing)

12) You must do it soon! (A response to scenario 5: ordering)

13) You really disap-disappoint me, why did you do this to me? (A response to scenario 5: expressing disappointment)

14) Don't repeat! And you must finish today. (A response to scenario 5: warning and order)

15) I am very unsatisfied... make me sad mam. (A response to scenario 6: expressing disappointment)

In situation 7, 8, and 9, Bald on record occurred in the strategy of warning, admonishing, asserting right, expressing annoyance/inconvenience, criticizing, and reproving.

16) Excuse me, you must stand in line. Look! Many people in here for photocopy material or books. (A response to scenario 7: admonishing)

17) What the hell! Your-your-your voice is not good. (A response to scenario 8: criticizing)

18) You should be fired from here! (A response to scenario 9: reproving)

19) Hey, be careful your guitar hit my shoulder! (A response to scenario 8:warning)

20) It is my turn! (A response to scenario 7: asserting right)

21) Sorry your song is bad! (A response to scenario 8: criticizing)

22) Sorry Mr. I have waited in here thirty minutes so I was- I wish give me the best service for my score. Thank you. (A response to scenario 9: annoyance)

\subsubsection{Positive Politeness}

Asking for reasons was the strategy of Positive politeness which was frequently used by the participants. This strategy was predominantly used to express annoyance.

23) Why do you-why'd you-why do you do this? As you know, this is the new camera. (A response to scenario 1)

24) Why are you late? I have said that this afternoon I will use this motorcycle to go to campus. (A response to scenario 2)

25) Why you forgot give me a money mom? I must pay my study last month. (A response to scenario 3)

26) Why you can forget about my order? It is important for our company. (A response to scenario 5)

27) Why-why you not responsible for your report? (A response to scenario 5)

28) Hey, why you get-why you get in front of the line. (A response to scenario 7)

29) Why you play your music very noisy? (A response. to scenario 8)

30) Mister why you not serve me in your work time? (A response to scenario 9)

Asking for a reason was also used to express dissatisfaction particularly for responding scenario 6 , for example:

31) Mr. why my score lecture structure 2 get $D$ ?

32) Miss. why I get the bad score?

33) Excuse me sir, why my score is bad? Beside that I have studied maximally.

Some excerpts indicated that the participants sounded as though they did not make a complaint at all, or in other words they accepted the complainable matters. This occurred particularly when they employed the strategy of seeking for an agreement or compromise, for example:

34) No problem, if you borrow careful. (A response to scenario 1)

35) Oh...ok it's fine, be on time next time. (A response to scenario 2)

36) It's OK dad, I can pay tomorrow. (A response to scenario 3)

37) Ok mom, no problem I will wait your transfer and I will borrow to my friend before that. (A response to scenario 3)

\subsubsection{Negative Politeness}

The strategy of being conventionally indirect and questioning comprised most Negative politeness, for example: 
38) What did you do with my camera last night? (A response to scenario 1)

39) Where are you going last time my sister? I was waiting you in-in here because I am-I would like to-I would-I would going to my campus. (A response to scenario 2)

40) I am so confused can you give me this money for me now? I need-I need it so much. (A response to scenario 2)

The strategy of being conventionally indirect was commonly phrased by the participants to make a request, primarily to respond scenario $4,5,7,8$, and 9 .

41) Excuse me, can you minimize your volume-can you minimize volume? I want to study because yesterday I must finished examination (A response to scenario 4)

42) You know it is the last day to presentation! (A response to scenario 5)

43) Hi bro I think you must (ngantri?) I think you must take a line with all friends in here because I am here almost fifteen minutes like all my friends in here. (A response to scenario 7)

44) Could you be nice please? (A response to scenario 8)

45) Can you search the data and please give, please we all here more attention. (A response to scenario 9)

\subsubsection{Off-Record}

Asking a rhetorical question was the most common Off-record strategy involved in complaints and mostly it was employed to express annoyance.

46) Hey Rudy! Are you stupid? This camera is expensive you know? (A response to scenario 1)

47) Niny, where... why do you late! What time is it? I want to take my motorcycle. (A response to scenario 2)

48) Hey brother! Are you never stay on the line? (A response to scenario 7)

49) Hey, what the hell was that? (A response to scenario 8)

50) Sorry sir, what are you doing? it's... it's ... it's information very important for me ...for me. (A response to scenario 9)

\subsection{The Use of Politeness across Different Status Levels}

\subsubsection{Close-Equal/Close-Lower/Close-Higher (Scenario 1, 2, and 3)}

Table 1 shows that Bald on record and Positive politeness were used more frequently than Negative politeness and Off-record across the three status levels. Bald on record was used in the complaints to close-higher and close-equal collocutors more or less similarly and it was used slightly less often to those of close-lower interlocutors. Positive politeness was used across the three status levels roughly similarly. Negative politeness was used to address complainees of close-higher and close-lower status approximately similarly, and it was used significantly the least often to those of close-equal. Off-record was used in the complaints to close-lower collocutors more often than it was to close-equal, and it was used significantly the least often to those of close-higher. Chi square test revealed that the differences in frequency of Off-record and Negative politeness across the three status levels were significant.

Table 1. The frequencies of politeness types used in Close-Higher/Close-Lower/Close-Equal

\begin{tabular}{lccccc}
\hline & Close-Equal & Close-Lower & Close-Higher & $\chi^{2}$ test & df 2, $\mathrm{p}=0.05$ \\
\hline Bald on record & 40 & 37 & 45 & 0.80 & \\
Positive politeness & 46 & 49 & 42 & 0.54 & 5.99 \\
Negative politeness & 3 & 15 & 13 & 8.0 & \\
Off-record & 7 & 15 & 3 & 8.96 & \\
\hline
\end{tabular}

*Significant difference is found when $\chi^{2}$ value $>5.99$

\subsubsection{Familiar-Equal/Familiar-Lower/Familiar-Higher (Scenario 4, 5, and 6)}

Table 2 reveals that Positive politeness was used to address complainees of familiar-higher status the most frequently and it was used to those of familiar-equal the least frequently. Bald on record was particularly high in the complaints to collocutors of familiar-equal and familiar-lower, and it was used considerably the least often to those of familiar-higher. Negative politeness was used in the complaints to familiar-equal collocutors more 
commonly than it was in the ones to those of familiar-higher, and it was applied the least frequently to familiar-lower complainees. Off-record was commonly used to address collocutors of familiar-lower considerably more often than it was to those of familiar-higher and familiar-equal. It can be summarized that complainees of familiar-equal status tended to be addressed with Bald on record or Negative politeness, whilst those of familiar-lower and familiar-higher were commonly addressed with Positive politeness.

Table 2. The frequencies of politeness types used in Familiar-Higher/Familiar-Lower/Familiar-Equal

\begin{tabular}{lccccc}
\hline & Familiar-Equal & Familiar -Lower & Familiar -Higher & $\chi^{2}$ test & df 2, $\mathrm{p}=0.05$ \\
\hline Bald on record & 53 & 36 & 14 & 22.27 & \\
Positive politeness & 18 & 51 & 73 & 32.38 & 5.99 \\
Negative politeness & 40 & 11 & 20 & 18.62 & \\
Off-record & 3 & 18 & 5 & 15.31 & \\
\hline
\end{tabular}

*Significant difference is found when $\chi^{2}$ value $>5.99$

\subsubsection{Unfamiliar-Equal/Unfamiliar-Lower/Unfamiliar-Higher (Scenario 7, 8, and 9)}

Table 3 indicates that Bald on record was used by the participants the most frequently across the three status levels. It was addressed to collocutors of unfamiliar-lower status significantly more often than it was to those of unfamiliar-higher and unfamiliar-equal. Positive politeness was commonly used to address collocutors of unfamiliar-equal and unfamiliar-higher more or less similarly, and it was used significantly the least often to those of unfamiliar-lower. Negative politeness was comparatively high particularly used to address unfamiliar-equal complainees. Off-record was used considerably the least often across the three status levels. The differences in frequency of Negative politeness and Off-record across the three status levels were not significant.

Table 3. The frequencies of politeness types used in Unfamiliar-Higher/Unfamiliar-Lower/Unfamiliar-Equal

\begin{tabular}{lccccc}
\hline & Unfamiliar-Equal & Unfamiliar-Lower & Unfamiliar-Higher & $\chi^{2}$ test & df 2, $\mathrm{p}=0.05$ \\
\hline Bald on record & 53 & 81 & 62 & 6.26 & \\
Positive politeness & 23 & 9 & 22 & 6.78 & 5.99 \\
Negative politeness & 27 & 16 & 17 & 3.7 & \\
Off-record & 4 & 7 & 5 & 0.88 & \\
\hline
\end{tabular}

$*$ Significant difference is found when $\chi^{2}$ value $>5.99$

\subsection{The Use of Politeness across Different Familiarity or Social Distance}

\subsubsection{Equal-Close/Equal-Familiar/Equal-Unfamiliar (Scenario 1, 4, and 7)}

As it is indicated by table 4 that the research participants commonly applied Bald on record across the three status levels with no significant difference. They used Positive politeness very frequently, particularly to address collocutors of equal-close and they employed Negative politeness very commonly to address collocutors of equal-familiar and equal-unfamiliar. They employed Off-record in low frequencies across the three social distances with no significant difference.

Table 4. The frequencies of politeness types used in Equal-Close/Equal-Familiar/Equal-Unfamiliar

\begin{tabular}{lccccc}
\hline & Equal-Close & Equal-Familiar & Equal-Unfamiliar & $\chi^{2}$ test & $\mathrm{df} 2, \mathrm{p}=0.05$ \\
\hline Bald on record & 40 & 53 & 53 & 2.32 & \\
Positive politeness & 46 & 18 & 23 & 15.38 & 5.99 \\
Negative politeness & 3 & 40 & 27 & 30.2 & \\
Off-record & 7 & 3 & 4 & 1.86 & \\
\hline
\end{tabular}

*Significant difference is found when $\chi^{2}$ value $>5.99$ 


\subsubsection{Lower-Close/Lower-Familiar/Lower-Unfamiliar (Scenario 2, 5, and 8)}

Table 5 points out that the research participants used Bald on record and Positive politeness very frequently. They used Bald on record to collocutors of lower-unfamiliar significantly the most often and used Positive politeness to those of lower-close and lower-familiar significantly very often. Negative politeness was employed more or less similarly across different social distances. Off-record strategy occurred in the complaints to collocutors of lower-familiar or lower-close more often than to those of lower-unfamiliar although the differences in frequency were not significant.

Table 5. The frequencies of politeness types used in Lower-Close/Lower-Familiar/Lower-Unfamiliar

\begin{tabular}{lccccc}
\hline & Lower-Close & Lower-Familiar & Lower-Unfamiliar & $\chi^{2}$ test & df 2, $\mathrm{p}=0.05$ \\
\hline Bald on record & 37 & 36 & 81 & 25.7 & \\
Positive politeness & 49 & 51 & 9 & 30.9 & 5.99 \\
Negative politeness & 15 & 11 & 16 & 1.0 & \\
Off-record & 15 & 18 & 7 & 4.8 & \\
\hline
\end{tabular}

*Significant difference is found when $\chi^{2}$ value $>5.99$

\subsubsection{Higher-Close/Higher-Familiar/Higher-Unfamiliar (Scenario 3, 6, and 9)}

Table 6 displays that to complain to interlocutors of higher-unfamiliar, the participants tended to apply Bald on record and to complain to those of higher-familiar they mostly used Positive politeness, whilst to those of higher-close they commonly utilized Positive politeness and Bald on record. The frequency of each strategy was differently distributed across the three social distances. Bald on record was used to address higher-unfamiliar collocutors more frequently than it was to those of higher-close, and it was used significantly the least often to those of higher-familiar. Positive politeness was used very often to complain to collocutors of higher-familiar and higher-close, and it was used relatively less often to those of higher-unfamiliar. Negative politeness was employed approximately similarly across the three social distances and it was used less often than it was either Bald on record or Positive politeness. Off-record was used the least often across social distances.

Table 6. The frequencies of politeness types used in Higher-Close/Higher-Familiar/Higher-Unfamiliar

\begin{tabular}{lccccc}
\hline & Higher-Close & Higher -Familiar & Higher -Unfamiliar & $\chi^{2}$ test & df 2, $\mathrm{p}=0.05$ \\
\hline Bald on record & 45 & 14 & 62 & 29.37 & \\
Positive politeness & 42 & 73 & 22 & 28.92 & \multirow{2}{*}{5.99} \\
Negative politeness & 13 & 20 & 17 & 1.48 & \\
Off-record & 3 & 5 & 5 & 0.62 & \\
\hline
\end{tabular}

* Significant difference is found when $\chi^{2}$ value $>5.99$

In line with previous findings by Trosborg (1995) and Frescura (1995), some complaints involving Bald on record tended to be abusive. Bald on record sounded very direct when it expressed annoyance and reproved complainee's wrong doing. The application of some Bald on record strategies suggested that the complainers intended to deliberately make offences to the complainees or they conducted Bald on record impoliteness (Culpeper, 1996). This commonly involved direct language, for example the one used in blaming, threatening, criticizing, and reproving. Some other excerpts indicated that the application of supporting moves, i.e. attention getters generated rudeness, for instance hey you crazy! (7) and hey you! (11). The application of harsh complaint by the learners might be due to the fact that they only interacted with an imaginative person so they lacked sufficient responsibility for what they were saying. Misconception about the stereotype of the target language speakers might also contribute to the use of direct language in Bald on record. The English learners like Indonesians in general misapprehend the stereotype of Westerners (American, British and Europeans) as direct (Hassal, 2004). Nevertheless as complaint is a speech act which is intrinsically abusive and impolite (Trosborg, 1995) the use of harsh language by the English learners could be warranted.

The high application of Positive politeness was predictable as complaints naturally threaten positive face of complainees in which complainers perform a negative evaluation to some aspects of the complainee's positive face (Brown \& Levinson, 1987). This can be observed when the English learners expressed some negative 
evaluation to a situation relating to the complainee's past and present action. Some excerpts suggested that in the one hand they intended their complaints to be observed directly but on the other hand they did not want to sound very direct, and hence they used the strategy of asking for reasons as a compromise. This is in line with Monzoni (2008b) that asking for reasons is the most common and easiest strategy to make a complaint.

Seeking for an agreement was another strategy of Positive politeness used by the learners. The strategy was realized through the use of accepting or forgiving strategy (see 36 and 37) in which the English learners who were mostly Javanese native speakers avoided making complaints to parents. The application of this strategy might be informed by their (Javanese) sociocultural background in which parents are very important persons who have to be highly respected and should not receive complaints or at least they get non-abusive ones. Displaying obedience to parents is a very polite conduct in Javanese (Suseno, 1997), but expressing politeness by submissively accepting complainable matters is rather peculiar and it is at odds with the nature of complaint (e.g. Edwards, 2005; Laforest, 2002; North, 2000).

Off-record strategy was scarcely used by the English learners. We predicted that this is due to the fact that Off-record is not always easy to perform since it requires high knowledge of how to violate Grice's maxim so as to generate polite complaints. An Off-record strategy which is relatively easy to perform by the learners is asking rhetorical questions, e.g. (46) to (49). This finding is in line with Koshik (2003) that asking rhetorical questions is the most pervasive strategy of complaints. Nevertheless, the over use of rhetorical questions across status levels seems to suggest that the learners involved a 'play it safe' strategy (Ellis, 1994) in which they might be uncertain about other pragmalinguistic resources which could express Off-record strategy. It should be noted however that asking a rhetorical question does not always mean that the learners sounded less direct since harsh or abusive complaints could be engendered by this strategy, e.g. (46) and (49).

\section{Conclusion}

The study reported the use of politeness strategies of Brown and Levinson in speech act of complaint by Indonesian learners of English. The results of the study revealed that different status levels and social distances induced different frequencies of politeness strategies rather than different types of politeness. Bald on record and Positive politeness were the most pervasive strategies used by the research participants. Both politeness strategies were used significantly different when interlocutors had familiar and unfamiliar relationships and they had different status levels (lower and higher). Negative politeness also occurred commonly but it was used less often than it was Bald on record and Positive politeness. It was used significantly different when interlocutors had close and familiar relationships. Off-record was employed the least often.

This study provides a better understanding of foreign language learners' pragmatic competence regarding the use of politeness strategies. However, since the strategies were elicited mainly through ODCT, they might not truly reflect the complexities of politeness strategies in their natural setting. Although ODCT could generate spontaneous responses, participants only interacted with unreal interlocutors therefore they might lack accountability for what they said. Other research instrument such as a role play is beneficial for future research.

In addition to social contexts underlying politeness usages there are pragmalinguistic means of conveying politeness which are different in every language, hence foreign language learners shall be made aware of them. Teaching intervention to this area could minimize aggressive interactions.

\section{Acknowledgements}

We would like to thank Universitas Muhammadiyah Surakarta for supporting this research and we appreciate LPPM-UMS which has helped the researchers with administrative supports. We also would like to thank the research participants for providing us with the research data.

\section{References}

Allami, Hamid. (2006). A Sociopragmatic Analysis of Griping: The case of Iranian students. The Linguistics Journal, 1, 59-76.

Al-Marrani, Y. M. A., \& Sazalie Azimah, Binti. (2010). Polite Request Strategies by Yemeni Females: A socio-pragmatic study. Modern Journal of Applied Linguistics, 2, 478-516.

Al-Eryani, Ali. (2007). Refusal strategies by Yemeni EFL learners. The Asian EFL Journal, 9(2), 19-31.

Amaya, Lucía Fernández. (2008). Teaching Culture: Is It Possible to Avoid Pragmatic Failure? Revista Alicantina de Estudios Ingleses, 21, 11-24.

Anderson, J. A. (2009). Polite Requests in Non-Native Varieties of English: The Case of Ghanaian English. LINGUISTIC ATLANTICA (Journal of the Atlantics Provinces Linguistic Association ), 30, 59-86. 
Astika, Dheftya, Cahya. (2013). The Influence of Social Distance, Status, and Gender on the Complaint Strategies by Indonesian EFL Learners. Unpublished undergraduate thesis, English Department, FKIP Universitas Muhammadiyah Surakarta, Surakarta.

Bachman, L. F. (1990). Fundamental Considerations in Language Testing. Oxford: Oxford University Press.

Bardovi-Harlig, K., Hartford, B. A. S., Mahan Taylor, R., Morgan, M. J., \& Reynolds, D. W. (1991). Developing pragmatic awareness: Closing the conversation. ELT Journal, 45(1), 4-15. http://dx.doi.org/10.1093/elt/45.1.4

Beebe, L. M., \& Cummings, M. C. (1996). Natural speech act data versus written questionnaire data: How data collection method affects speech act performance. In S. M. Gass, \& J. Neu (Eds.), Speech Acts across Cultures (pp. 65-86). Berlin: Mouton de Gruyter.

Boxer, Diana. (1993a). Complaints as positive strategies: What the learner needs to know. TESOL QUARTERLY, 27(2), 277-299. http://dx.doi.org/10.2307/3587147

Boxer, Diana. (1993b). Social distance and speech behaviour. The case of indirect complaint. Journal of pragmatics, 19, 103-125. http://dx.doi.org/10.1016/0378-2166 (93)90084-3

Brown, Penelope, \& Levinson, Stephen, C. (1987). Politeness: Some Universal in Language Usage. Cambridge: Cambridge University Press.

Culpeper, Jonathan. (1996). Toward an anatomy of impoliteness. Journal of Pragmatics, 25, 349-367. http://dx.doi.org/10.1016/0378-2166 (95)00014-3

Drew, Paul. (1998). Complaints about transgressions and misconduct. Research on Language and Social Interaction, 31(3/4), 295-325. http://dx.doi.org/10.1080/08351813.1998.9683595

Edwards, Derek. (2005). Moaning, whinging and laughing: The subjective side of complaints. Discourse Studies, 7, 5-29. http://dx.doi.org/10.1177/1461445605048765

Ellis, Rod. (1994). The Study of Second Language Acquisition. Oxford: Oxford University Press.

Felix-Brasdefer, J. C. (2006). Linguistic politeness in Mexico: Refusal strategies among male speakers of Mexican Spanish. Journal of Pragmatics, 38, 2158-2187. http://dx.doi.org/10.1016/j.pragma.2006.05.004

Fraser, Bruce. (2010). Pragmatic Competence: the Case of Hedging. In Kaltenbock, G., Mihatsch, W., \& Schneider, S. (Eds.), Studies in Pragmatics 9: New Approaches to Hedging (pp. 15-34). Bingley: Emerald Group Publishing Ltd.

Frescura, M. (1995). Face orientations in reacting to accusatory complaints: Italian L1, English L1, and Italian as a community language. Pragmatics and Language Learning, 6, 79-108.

Goffman, Erving. (1967). Interactional Ritual: Essays on face to face behavior. New York: Doubleday.

Golato, A. (2003). Studying compliment responses: A comparison of DCTs and recordings of naturally occurring talk. Applied Linguistics, 24(1), 90-121. http://dx.doi.org/10.1093/applin/24.1.90

Gu, Yueguo. (1990). Politeness phenomena in modern Chinese. Journal of Pragmatics, 14(2), 237-257. http://dx.doi.org/10.1016/0378-2166 (90)90082-O

Hassal, Tim. (2004). Through a glass, darkly: When learner pragmatics is misconstrued. Journal of Pragmatics, 36, 997-1002. http://dx.doi.org/10.1016/j.pragma.2003.09.001

Hinkel, E. (1997). Appropriateness of advice: DCT and multiple choice data. Applied Linguistics, 18, 1-26. http://dx.doi.org/10.1093/applin/18.1.1

Ide, S. (1992). On the notion of Wakimae: Towards an integrated framework of linguistic politeness. Mosaic of language: Essay in honour of Professor Natsuko Okuda. Mejiro Linguistic Society (MLS), 298-305.

Jefferson, Gail. (1988). On the sequential organization of troubles-talk in ordinary conversation. Social Problems, 35(4), 418-441. http://dx.doi.org/10.1525/sp.1988.35.4.03a00070

Koshik, Irene. (2003). Wh-questions used as challenges. Discourse Studies, 5(1), 51-77. http://dx.doi.org/10.1177/1461445603005001839

Kraft, Bettina, \& Geluykens, Ronald. (2002). Complaining in French L1 and L2: A cross-linguistic investigation. EUROSLA Yearbook, 2, 227-242

Kwon, Jihyun. (2004). Expressing refusals in Korean and in American English. Multilingua, 23, 339-364. http://dx.doi.org/10.1515/mult.2004.23.4.339 
Laforest, Marty. (2002). Scenes of family life: complaining in everyday conversation. Journal of Pragmatics, 34, 1595-1620. http://dx.doi.org/10.1016/S0378-2166 (02)00077-2

Lakoff, Robin. (1977). What can you do with words: politeness, pragmatics, and performative. In Rogers, Andy (Ed.), Proceedings of the Texas Conference on Performative, Presuppositions and Implicature. Arlington: Center for Applied Linguistics.

Leech, Geoffrey. (1983). Principles of Pragmatics. London: Longman.

Lihui, Zheng, \& Jianbin, Huang. (2010). A study of Chinese EFL learners' pragmatic failure and the implications for college English teaching. Polyglossia, 18, 41-54.

Marazita, L. R. A. (2009). The Role of Negative Politeness in Request: The Strategies that Non-Native Speakers Apply and Fail to Apply when Performing Request. Journal of NELTA, 14(1/2), 82-90.

Matsumoto, Y. (1988). Reexamination of the universality of face: Politeness phenomena in Japan. Journal of Pragmatics, 12, 403-426. http://dx.doi.org/10.1016/0378-2166 (88)90003-3

Monzoni, Chiara, M. (2008a). Direct complaints in (Italian) calls to the ambulance: The use of negatively framed questions. Journal of Pragmatics, 41, 2465-2478. http://dx.doi.org/10.1016/j.pragma.2008.09.042

Monzoni, Chiara M. (2008b). Introducing direct complaints through questions: The interactional achievement of 'pre-sequences'? Discourse Studies, 10, 73-87. http://dx.doi.org/10.1177/1461445607085591

Moon, K. (2002). Speech act study: Differences between native and non-native speakers' complaint strategies. TESOL Working Papers series 1. College of Arts and Sciences, American University.

Murphy, B., \& Neu, J. (1996). My grade's too low: The speech act set of complaining. In S. M. Gass, \& J. Neu (Eds.), Speech acts across cultures (pp. 191-216). Berlin: Mouton de Gruyter.

North, Scott. (2000). Cultures of complaint in Japan and the United States. Working Paper, 17. The Sociology Department at the University of California, Berkeley.

Oktoprimasakti, Fransiska. (2006). Direct and indirect strategies of refusing among Indonesians. Department of English and Letter, Sanata Darma University. Phenomena: Journal of language and Literature, 10(2), 103-115.

Olshtain, Elite, \& Weinbach, Liora. (1993). Interlanguage features on the speech act of complaining. In Kasper, G., Blum-Kulka, S. (Eds.), Interlanguage Pragmatics (pp. 108-122). Oxford: Oxford University Press.

Prawito, Hainess. (2007). The refusals strategies to a date invitation used by female Chinese students and female Javanese students in Surabaya. Unpublished thesis, English Department, Faculty of Letters, Petra Christian University, Surabaya.

Sadler, Randall, W., \& Eroz, Betil. (2002). "I refuse you!” An examination of English refusals by native speakers of English, Lao, and Turkish. Arizona Working Paper in SLAT, 9, 53-80.

Sauer, M. (2000). Complaints: A cross-cultural study of pragmatic strategies and linguistic forms. Paper presented at $A A A L$ Conference, Vancouver, Canada.

Schegloff, Emanuel, A. (1988). On an actual virtual servo-mechanism for guessing bad news: A single case conjecture. Social Problems, 35(4), 442-457. http://dx.doi.org/10.2307/800596

Seran, Dogancay, Aktuna, \& Sibel, Kamisli. (1997). Pragmatic transfer in interlanguage development: A case study of advanced EFL learners. Paper presented at the National Linguistics Conference (11th Ankara, Turkey, May 1997).

Suseno, Franz-Magnis. (1997). Javanese Ethics and World View. The Javanese Idea of Good Life. Jakarta: Gramedia.

Taguchi, Naoko. (2008). The role of learning environment in the development of pragmatic comprehension: A comparison of gains between EFL and ESL learners. Studies on Second Language Acquisition, 30, 423-452. http://dx.doi.org/10.1017/S0272263108080716

Traverso, Veronique. (2008). The dilemmas of third-party complaints in conversation between friends. Journal of Pragmatics, 41, 2385-2399. http://dx.doi.org/10.1016/j.pragma.2008.09.047

Tanck, Sharyl. (2002). Speech act sets of refusal and complaint: A comparison of native and non native English speakers' production. Working paper written for TESL 523 Second Language Acquisition. American University, Washington DC. 
Thomas, Jenny. (1983). Cross cultural pragmatic failure. Applied Linguistics, 4, 91-112. http://dx.doi.org/10.1093/applin/4.2.91

Trosborg, Anna. (1995). Interlanguage Pragmatics. Requests, Complaints and Apologies. Berlin: Mouton de Gruyter. http://dx.doi.org/10.1515/9783110885286

Umar, Abdul, Majeed, Al-Tayib. (2006). The speech act of complaint as realized by advanced Sudanese learners of English. Umm Al-Qura University Journal of Educational, Social Sciences and Humanities, 18(2), 9-40.

Wijayanto, Agus. (2013). The emergence of Javanese sopan and santun (politeness) on the refusal strategies used by Javanese learners of English. The Internet Journal of Language, Culture and Society, 36, 34-47.

Yang, Jia. (2008). How to say "No" in Chinese. Proceedings of the 20th North American Conference on Chinese Linguistics (NACCL20), 2, 1041-1058. The Ohio State University.

\section{Appendix}

DCT Scenarios

Direction

- Read the scenarios before you answer them.

- Please imagine that you are in the situation as described by each DCT scenario.

- Respond each DCT scenario spontaneously as you do in face-to-face interaction.

1. Your close friend borrows your new digital camera to take seascapes views. When he returns your camera you find that the lens of your camera is broken. You complain your friend about it.

You say: ...

2. Your brother borrows your motorcycle to visit his friend. You say that you are going to ride your motorcycle to go to your campus at 2 o'clock. Your brother promises you to return it as soon as possible. Now you are about leaving for your campus but your brother has not come up yet. Finally your brother comes home very late. He says that he has forgotten that you are going to go to campus. You make a complaint to your brother.

You say: ...

3. You are a student of a university. You asked for your tuition fee to your father three days ago. Your father promises that you will receive the money today. Now you are going to go to your campus to pay for your tuition fee as today is the deadline to pay it. Unfortunately when you ask the money to your father he says that he has forgotten to take the money from the bank. He is going to give you the money this afternoon or tomorrow morning. You complain your father about it.

You say: ...

4. You are living at a dormitory. It is 22.30 now and you are still studying for the exam tomorrow morning. You are hearing the neighbour next door is playing rock music. The music is getting louder and louder and disturbs your concentration. You go to your neighbour next door to complain about it.

You say: ...

5. You are working at an electronic company. You are a sales supervisor. You asked one of your staffs to make a sales report last week. As it was promised that the report will be ready this morning. Now you need the report and you will send it to Jakarta. You ask the staff for it, but he says that it has not been completed. You make a complaint to him.

$$
\text { You say: ... }
$$

6. You are reading the result of the final exam on the announcement board at your department. You find out that the score of your Structure II subject which you predict you will get A is D. You are not happy with the score. You meet the lecturer and make a complaint.

$$
\text { You say: ... }
$$

7. You are at a copy service centre for copying a book chapter. Now you and other students are queuing for about 15 minutes. A student whom you do not know cuts the queue and asks the staff to copy his documents. It seems that he knows the staff well. You make a complaint to the student.

$$
\text { You say: ... }
$$


8. You are living in Yogyakarta city. To go to your university you always take a bus. Now you are at a bus leaving for your university. On the way a busker is getting on your bus. He is playing his music just close to you and singing a song very loudly. The song is not melodious and it tends to annoy your ears. He also brushes your shoulder with his guitar several times. You are not very happy so you make a complaint to him.

You say: ...

9. You are going to the administrative office to ask some information about your examination scores which you have not obtained. You are queuing at the office for about 30 minutes. Now it is your turn. You try to explain that you have not received your exam scores but the office staff is talking with others about the film they watched on $\mathrm{TV}$, you are being ignored. You are not happy with it so you make a complaint to the staff.

You say: ...

\section{Copyrights}

Copyright for this article is retained by the author(s), with first publication rights granted to the journal.

This is an open-access article distributed under the terms and conditions of the Creative Commons Attribution license (http://creativecommons.org/licenses/by/3.0/). 